\title{
Association of Self-Concept with Oral Health Status among Children Residing in Orphanages in Bengaluru
}

\author{
Thara Chandran ${ }^{1}$, Nagashree Savanur Ravindranath², Rekha Raju ${ }^{3}$, \\ Soumi Samuel ${ }^{4}$, Jesline Merly James ${ }^{5}$, Freddy Mistry ${ }^{6}$
}

\begin{abstract}
${ }^{1}$ Department of Public Health Dentistry, AB Shetty Memorial Institute of Dental Sciences (ABSMIDS), Deralakatte, Mangalore, Karnataka, India. 2, 3 Department of Public Health Dentistry, Vokkaligara Sangha Dental College \& Hospital, Bengaluru, Karnataka, India, ${ }^{4}$ Department of Oral and Maxillofacial Surgery, AB Shetty Memorial Institute of Dental Sciences (ABSMIDS), Deralakatte, Mangalore, Karnataka, India.

5Department of Public Health Dentistry, Indira Gandhi Institute of Dental Sciences, Nellikuzhy,

Kothamangalm, Kerala India, ${ }^{6}$ Department of Dentistry, University of Toronto, Ontario, Canada,
\end{abstract}

\section{ABSTRACT}

\section{BACKGROUND}

Self-concept is a fundamental domain of a person's psychological function. Relation with family members and peers may influence self-concept which poses children in orphanages at risk. In order to implement and evaluate oral health interventions, we need to consider the functional and psychosocial dimensions of oral health. The purpose of this study was to assess the association between self-concept and oral health status among 12 - 17 year olds residing in orphanages in Bengaluru.

\section{METHODS}

The study was carried out among children living in orphanages. A cluster sampling method was used to select 269 participants from 9 orphanages in Bengaluru.

The self-concept of the study participants was assessed using R. K. Saraswat's selfconcept questionnaire. Oral health status was recorded using world health organization (WHO) oral health assessment form 2013.

\section{RESULTS}

Majority of the children in orphanages had an above average ( $45 \%$ ) and average selfconcept (39\%). Dental caries was present in $91.1 \%$, missing teeth in $19.7 \%$, filled teeth in $20.4 \%$, dental trauma in 17.9 , gingival bleeding in $14.5 \%$, erosion in $5.9 \%$ and oral mucosal lesions in $10.03 \%$ of study participants.

\section{CONCLUSIONS}

Orphan children have an above average self-concept but are at an increased risk for oral diseases.

\section{KEY WORDS}

Self-Concept, Dental Caries, Gingivitis, Trauma, Orphanage
Corresponding Author:

Dr. Soumi Samuel,

Department of Oral and Maxillofacial Surgery, Nitte (Deemed to Be University) $A B$ Shetty Memorial Institute of Dental Sciences, (ABSMIDS)

Derlakatte, Mangalore, Karnataka, India

E-mail: soumisamuel@gmail.com

DOI: $10.14260 / \mathrm{jemds} / 2021 / 570$

How to Cite This Article:

Chandran T, Ravindranath NS, Raju R, et al. Association of self-concept with oral health status among children residing in orphanages in Bengaluru. J Evolution Med Dent Sci 2021;10(33):2795-2798, DOI: $10.14260 / \mathrm{jemds} / 2021 / 570$

Submission 13-02-2021,

Peer Review 02-06-2021,

Acceptance 09-06-2021,

Published 16-08-2021.

Copyright (C) 2021 Soumi Samuel et al. This is an open access article distributed under Creative Commons Attribution License [Attribution 4.0 International (CC BY 4.0)] 


\section{BACKGROUND}

Children who have lost their parents are often socially and economically deprived. About 2 million children in India mark the orphan population. ${ }^{1}$ Orphanages provide food, shelter and physical security but lack psychological secutity. ${ }^{2}$ Orphanages may have a negative impact on adolescents owing to their poor physical conditions, lack of adequate personnel, and lack of family support. ${ }^{3}$ Being socially disadvantaged is an important predictor of poor oral health as inmates in orphanages rarely get an opportunity to seek early dental care.

Self-concept pertains to the way an individual looks at oneself. The early psychological problems, homogeneity of environments and relative monotony leads to a negative impact on self-concept in institutionalized orphans. ${ }^{4}$ During the formative years from birth to 18 years, the environment as well as the people with whom an individual lives, shape his self-concept. The significant others include parents, siblings, teachers, and peers. ${ }^{5}$ Being deprived of the family environment, these children may feel lonely and experience various emotional conflicts negatively impacting their selfconcept.

The depression and withdrawal that follows can lead to immune suppression putting children at risk for various infectious and communicable diseases and malnutrition leading to an overall poor health. Oral and dental health is closely linked to the broader context of general health. The high prevalence and incidence of oral diseases make it a major public health concern across the globe. ${ }^{6}$ Previous studies conducted in orphanages in India revealed that the prevalence of oral diseases is high among the institutionalized children. ${ }^{7}$ A study by Shanbhog $\mathrm{R}$ et al. found a higher prevalence of dental caries, gingivitis and poor oral hygiene status among orphans. ${ }^{8}$ Virk P et al. showed that orphans had an above average self-concept and a high risk for dental caries while Gursoy F demonstrated a lower self-concept in orphans. 4,9

Untreated oral diseases could lead to general health problems, pain, difficulties in mastication, school absenteeism and also social unacceptability. Recognition of these problems is essential to provide optimum oral health for these deprived children. However, no such studies are conducted in Bengaluru city. The present study was conducted to assess the oral health status of the study population and to look for any association of self-concept with oral health in 12 - 17 years old children residing in orphanages.

\section{METHODS}

The cross-sectional study was conducted to assess the association of self-concept with oral health status among 12 17 years old inmates residing in orphanages in Bengaluru city. Inmates with any handicapping conditions and systemic diseases or conditions were excluded from the study.

Data was collected from January 2016 to September 2016. A list of government run and private orphanages in Bengaluru city was obtained from The Department of Women and Child Development. Cluster sampling was done to obtain the participants. It consisted of 39 orphanages each of which served as a cluster. From the clusters, orphanages were selected by lottery method and all members of the selected clusters were enrolled into the study. In this manner, 9 orphanages were selected.

Sample size was calculated using the formula

$\mathrm{n}=\mathrm{N}^{*} \mathrm{X} /\left[(\mathrm{N}-1) * \mathrm{E}^{2}+\mathrm{X}\right]$

where $\mathrm{N}=$ Population size (593)

$\mathrm{X}=\mathrm{Z} *(\mathrm{C} / 100)^{\wedge} 2 * \mathrm{r} *(100-\mathrm{r})$

$\mathrm{r}=$ Fraction of responses $(50 \%)$

$\mathrm{E}=\operatorname{Error}(5 \%)$

$\mathrm{Z}=$ Value of standard variate at given confidence interval (1.96).

The estimated sample size was 250 . The final participants were 269 when all inmates in 9 orphanages who met the inclusion criteria were included. The ethical clearance was obtained from the Institution Review Board of Research Studies and Ethics Committee at Vokkaligara Sangha Dental College and Hospital, Bengaluru. All participants were informed about the purpose and design of the study and informed consent was obtained from children above 15 years. For children below 15 years, permission was obtained from the care takers of the orphanages. Data was collected using questionnaires and clinical examination was done.

Self-concept questionnaire was used to assess the selfconcept of the study participants. It is a pre-validated questionnaire consisting of forty-eight questions given by R. K. Saraswat. ${ }^{10}$ The self-concept inventory provides six separate dimensions of self-concept - physical, social, intellectual, moral, educational, and temperamental self-concept. It also gives a total self-concept score. Each item of the questionnaire was provided with five alternatives to give responses ranging from most acceptable to least acceptable description of selfconcept. The summated score for all 48 items provides the total self-concept score of an individual. A high score on this inventory indicates a higher self-concept, while a low score shows low self-concept.

The clinical examination was carried out in the orphanages on a normal chair under natural light using mouth mirror and WHO probe. For clinical examination, full mouth oral examination was performed to record dentition status, periodontal status, enamel fluorosis, dental erosion, dental trauma, and oral mucosal lesions according to the criteria given by World health organization in 2013.11

A pilot study was conducted to find out the feasibility of the study, for training and calibration of the investigator and to check for the test-retest reliability of the questionnaire. Questionnaires were translated to Kannada prior to pilot study and back translation was done by an independent translator. Corrections were made wherever needed and the final questionnaire was compiled.

\section{Statistical Analysis}

Statistical analysis was done by Statistical Package for Social Sciences (SPSS) version 21. Association was evaluated using chi-square test. $\mathrm{P}<0.05$ was considered statistically significant. 
RESULTS

A total of 269 participants were included in the study. The mean age of the study group was $14.19 \pm 1.62$ years. Among them 159 (59.1\%) were males and 110 (40.9\%) were females. Upon clinical examination of study subjects, 245 participants had dental decay as the most common clinical finding followed by 55 with filled and 53 with missing teeth. Trauma to teeth was found in 49 , gingival bleeding in 39 , oral mucosal lesions in 27 and erosion in 16 study participants. There was no significant relationship between age and various dimensions of self-concept including total self-concept. No significant relationship was found between gender and individual dimensions of self-concept except for physical and temperamental dimension. For physical dimension, 76 (47.7 $\%)$ males had above average self-concept and 50 (31.4\%) had average self-concept. While for females, 48 (43.6\%) had an average self-concept and 33 (30\%) had above average selfconcept $(\mathrm{P}=0.03)$.

For temperamental dimension, $75(47.1 \%)$ males had an above average self-concept and $58(36.4 \%)$ had average selfconcept. While for females, 53 (48.1\%) had an average selfconcept and 32 (29\%) had above average self-concept (P = 0.03). None of the clinical parameters, caries experience, bleeding, erosion, trauma, and oral mucosal lesions were significantly associated with gender. Caries experience $(\mathrm{P}=$ 0.05), trauma $(P=0.001)$ and bleeding $(P=0.0001)$ were significantly associated with self-concept while erosion and oral mucosal lesions were not significantly associated. 25 (51 $\%)$ of the children with trauma and 20 (51.3\%) children with bleeding had an average self-concept. $114(44.2 \%)$ of the participants with caries experience and 13 (48.1\%) with oral mucosal lesions had an above average self-concept. For children with erosion, 12 (75\%) participants were equally distributed for above average and average categories of selfconcept.

\begin{tabular}{|c|c|c|c|c|c|}
\hline $\begin{array}{l}\text { Self - Concept } \\
\text { Dimension }\end{array}$ & High & $\begin{array}{c}\text { Above } \\
\text { Average }\end{array}$ & Average & $\begin{array}{c}\text { Below } \\
\text { Average }\end{array}$ & Low \\
\hline Physical & 28 & 109 & 98 & 32 & 2 \\
\hline Social & 28 & 112 & 105 & 24 & 0 \\
\hline Temperamental & 26 & 107 & 111 & 25 & 0 \\
\hline Educational & 19 & 113 & 112 & 24 & 1 \\
\hline Moral & 20 & 102 & 120 & 27 & 0 \\
\hline Intellectual & 28 & 111 & 98 & 32 & 0 \\
\hline Total Self - Concept Score & 23 & 121 & 105 & 20 & $\mathbf{0}$ \\
\hline \multicolumn{6}{|c|}{$\begin{array}{l}\text { Table 1. Distribution of Study Partcipants } \\
\text { Based on Dimensions of Self-Concept }\end{array}$} \\
\hline
\end{tabular}

\begin{tabular}{|c|c|c|c|c|c|c|}
\hline \multicolumn{2}{|c|}{$\begin{array}{c}\text { Clinical } \\
\text { Parameter }\end{array}$} & \multirow{2}{*}{$\begin{array}{c}\text { High } \\
21\end{array}$} & \multirow{2}{*}{$\begin{array}{c}\text { Above } \\
\text { Average } \\
114\end{array}$} & \multirow{2}{*}{$\begin{array}{c}\text { Average } \\
103\end{array}$} & \multirow{2}{*}{$\begin{array}{c}\text { Below } \\
\text { Average } \\
20\end{array}$} & \multirow{3}{*}{$\begin{array}{c}\text { P Value } \\
0.05\end{array}$} \\
\hline Caries & Present & & & & & \\
\hline experience & Absent & 2 & 7 & 2 & 0 & \\
\hline \multirow{2}{*}{ Trauma } & Present & 1 & 15 & 25 & 8 & \multirow{2}{*}{0.001} \\
\hline & Absent & 22 & 106 & 80 & 12 & \\
\hline \multirow{2}{*}{ Erosion } & Present & 1 & 6 & 6 & 3 & \multirow{2}{*}{0.72} \\
\hline & Absent & 22 & 115 & 99 & 17 & \\
\hline \multirow{2}{*}{ Bleeding } & Present & 3 & 8 & 20 & 8 & \multirow{2}{*}{0.001} \\
\hline & Absent & 20 & 113 & 85 & 12 & \\
\hline \multirow{2}{*}{$\begin{array}{c}\text { Oral } \\
\text { mucosal } \\
\text { lesions }\end{array}$} & Present & 2 & 13 & 10 & 2 & \multirow[b]{2}{*}{0.97} \\
\hline & Absent & 21 & 108 & 95 & 18 & \\
\hline
\end{tabular}

\section{DISCUSSION}

The potential contribution of psychological factors in understanding any disease process, as well as improving risk prediction is gaining attention. Self-concept has been described as nucleus of personality. 12 The factors determining the formation of self-concept are the environment as well as people with whom the individual lives which includes parents and siblings especially during adolescence, which are deprived in an orphan. The results of this cross-sectional study on children of orphanages provided an opportunity to analyse self-concept and oral health status in this left out population of society. The results of our study are in accordance with the study conducted by Parthasarathy and Swaminathan who stated that orphan children had a higher self-concept.13 However, the results are in contrary to the study by Gursoy $F$ et al. who found that self-concept of adolescents living in orphanages are lower than those not living in orphanages. ${ }^{9}$ In the present study, only $8.6 \%$ participants had high average self-concept. This is in contrast to the study by Malhotra G et al. in which $45 \%$ participants had high average self-concept. ${ }^{14}$

The studies stating the dental caries status of institutionalized children are scarce in India. The high prevalence of caries can be due to lack of proper oral hygiene measures, improper method of brushing and lack of access to treatment and preventive measures. The results were in accordance with the study by Shanbhog R et al. in which 88.5 $\%$ participants had at least one decayed teeth and in contrast with the study by Khare $\mathrm{V}$ et al. where only $41 \%$ participants had decayed permanent teeth. ${ }^{15,16}$ The major differences between the decayed and filled component indicate poor professional services to this group. Lack of facility for early and regular oral health check-up, and cost of treatment maybe the reasons for accumulated treated needs. There is a general belief that institutionalized children have fewer caries lesions owing to the diet provided in the orphanage. In our study, not all children were present in the orphanage from birth. This could have resulted in a higher caries experience before being institutionalized. Taanenbaum and Miller reported that caries attack rate was less in children staying in the institution for a longer period. ${ }^{17}$

Gingival bleeding was present in $14.5 \%$ study participants. Gingivitis associated with teeth eruption and hormonal changes at puberty may have also negatively contributed to the poor oral hygiene maintenance in them thereby causing gingival bleeding. Poor oral health behaviour, poor tooth brushing frequency and poor flossing frequency and decreased frequency of dental attendance maybe the other contributing factors to gingival bleeding. This finding was in contrast with the study by M. Khadekar et al. where 58 $\%$ of the participants had gingivitis and in agreement with the study by $\mathrm{Al}$ - Jobair AM et al. where gingivitis was present in $20 \%$ of the participants. ${ }^{18,19}$

Oral mucosal lesions were found in only $10.03 \%$ of the study participants. These included traumatic ulcers, aphthous ulcers, fistula, abscess and herpetic lesions. Very few studies were made on the prevalence of oral mucosal lesions among orphans. The present finding is in accordance with the study by $\mathrm{Al}$ - Maweri SA et al. who found that $37 \%$ orphans had some form of oral mucosal lesions. ${ }^{20}$

Two major causes for oral mucosal lesions can be nutritional deficiencies and psychological stress which can be related to a low level of self-concept. Erosion was reported in $5.9 \%$ of the study participants. This could be attributed to consumption of lemonade and other soft drinks. A similar 
result was observed by $\mathrm{Al}$ - Malik $\mathrm{M}$ et al. in his study on institutionalized children, where $16.3 \%$ inmates had dental erosion. ${ }^{21}$ Our study showed no significant association between erosion and self-concept.

The present study revealed that $17.9 \%$ participants had teeth with trauma which was negatively and significantly correlated with self-concept. Enamel fracture accounted for 4 $\%$, enamel and dentine fracture $11 \%$ and pulp involvement was seen in $2.9 \%$ study participants. The overcrowded orphanage environment and psychological stress faced by the inmates may be the contributing factors towards dental trauma.

\section{CONCLUSIONS}

The findings of this study suggest that awareness on the importance of oral health needs to be enhanced among the orphanage children of Bengaluru. The results showed that orphan children are potentially at an increased risk of poor oral health. More subjects were present in above average and average self-concept groups. None of the subjects were in low self-concept group, which is suggestive of a high self-concept in our study subjects. The study showed a significant negative correlation of caries, gingival bleeding, and dental trauma with self-concept.

Data sharing statement provided by the authors is available with the full text of this article at jemds.com.

Financial or other competing interests: None.

Disclosure forms provided by the authors are available with the full text of this article at jemds.com.

\section{REFERENCES}

[1] Rutala WA, Weber DJ. Disinfection and sterilization in health care facilities: what clinicians need to know. Clin Infect Dis 2004;39(5):702-9.

[2] Huynh HV, Limber SP, Gray CL, et al. Factors affecting the psychosocial well-being of orphan and separated children in five low-and middle-income countries: Which is more important, quality of care or care setting? PLoS One 2019:14(6):e0218100.

[3] Adamowicz - Kleplaska B, Burkiewicz B. Oral condition in children and adolescents exposed to sociopathies. Czas Stomatol 1990;43:679 - 84.

[4] Virk P, Jain RL, Pathak A, Sharma U, Rajput JS. Inter relationship of intelligence - quotient and selfconcept with dental caries amongst socially handicapped orphan children. J Indian Soc Pedod Prev Dent 2012;30:127 - 32.

[5] Mazhari F, Ajami BAM, Ojrati N. Dental treatment needs of 6 - 12 - year old children in mashhad orphanages in 2006Journal of mashhad dental school2008,32(1); 81 - 6.

[6] O'Sulliivan EA, Stephens AJ. The oral and dental status of children residing in a Romanian orphanage.International Journal of Paediatric Dentistry 1997; 7: 41 - 42.
[7] Agrawal A, Bhat N, Shetty S, Sharda A, Singh K, Chaudhary $\mathrm{H}$. Oral hygiene and periodontal status among detainees in a juvenile detention center, India. Oral Health Prev Dent. 2011;9(3):281 - 7.

[8] Camacho GA, Camacho E, Rodríguez RA, Guille AJ, Juarez HM,Perez G. Predisposing factors for dental caries in girls at an orphanage of Mexico City.Acta Pediatr Mex 2009;30(2):71 - 76.

[9] Gürsoy F, Biçakçi MY, Orhan E, Bakırcı S,Çatak S, Yerebakan 0. Study on Self - Concept Levels of Adolescents in the Age Group of 13 - 18 who Live in Orphanage and those who do not Live in Orphanage. International Journal of Social Sciences and Education 2012;2(1):56 - 66.

[10] Saraswat R.K. Self - concept questionnaire. Agra: National Psychological Corporation, 1984

[11] World Health Organization.Oral health surveys:basic method.5th edition.

[12] Ahad R, Ara S, Shah SA.Self - Concept and Aggression among Institutionalised Orphans of Kashmir.The International Journal of Indian Psychology 2016;3(2):104 - 16.

[13] Parthasarathy D, Swaminathan VD. Self - concept among normal,destitute and orphan. Indian J Appl Psychol 1992;29:56 - 60.

[14] Malhotra G, Navit S, Rallan M, Mayall S, Goel I.Association Between Self - Concept And Gingivitis In 10 - 15 Yr Old Children Of Moradabad City. Annals of Dental Specialty 2014;2(2):38 - 42.

[15] Shanbhog R, Godhi BS, Nandlal B, Kumar SS, Raju V, Rashmi S. Clinical consequences of untreated dental caries evaluated using PUFA index in orphanage children from India. J Int Oral Health 2013; 5(5):1 - 9.

[16] Khare V, Koshy A, Rani P, Srilatha S, Kapse SC, Agrawal A.Prevalence of dental caries and treatment needs among the orphan children and adolescents of Udaipur district, Rajasthan, India.J Contemp Dent Pract. 2012 Mar $1 ; 13(2): 182-7$.

[17] Tannenbaum KA, Miller JW. Oral condition of mentally retarded patient. J Dent Child 1960;27:277 - 80.

[18] Khedekar M, Suresh KV, Parkar MI, Malik N, Patil S, Taur S, Pradhan D.Implementation of Oral Health Education to Orphan Children. Journal of the College of Physicians and Surgeons Pakistan 2015, Vol. 25 (12): 856 - 859.

[19] Al - Jobair AM, Al - Sadhan SA, Al - Faifi AA,Andijani RI, Al - Motlag SK.Medical and dental health status of orphan children in central Saudi ArabiaSaudi Med J 2013; 34(5):531 - 36.

[20] Al - Maweri SA, Al - Soneidar WA, Halboub ES. Oral lesions and dental status among institutionalized orphans in Yemen: A matched case - control study. Contemp Clin Dent 2014;5:81 - 4 .

[21] Al - Malik M, Holt RD. The prevalence of caries and of tooth tissue loss in a group of children living in a social welfare institute in Jeddah, Saudi Arabia. International Dental Journal 2000; 50: 289 - 92. 